\title{
KOMPARASI EFISIENSI PENGGUNAAN TRAKTOR, TERNAK KERBAU DAN TENAGA MANUSIA DALAM PENGOLAHAN LAHAN USAHATANI PADI
}

\section{COMPARISON OF THE EFFICIENCY OF USE OF TRACTORS, BUFFALO AND HUMAN POWER IN LAND PROCESSING OF PADDY FARMING}

\author{
Tedi Hartoyo*, M. Iskandar Mamoen, Unang Atmaja, Hendar Nuryaman \\ Fakultas Pertanian, Universitas Siliwangi \\ *Corresponding email: tedihartoyo@unsil.ac.id. \\ (Diterima 30-10-2018; Disetujui 10-01-2019)
}

\begin{abstract}
ABSTRAK
Penelitian ini bertujuan untuk menyusun analisis kapasitas kerja, besarnya biaya dan komparasi efisiensi penggunaan traktor (hand tractor), ternak kerbau dan tenaga kerja manusia dalam pengolahan lahan usahatani padi sawah. Penelitian dilaksanakan dengan metode survey di wilayah Kota Tasikmalaya. Berdasarkan hasil analisis, penelitian ini dapat disimpulkan terdapat perbedaan yang signifikan antara besarnya kapasitas, biaya penggunaan traktor, ternak dan tenaga manusia dalam pengolahan lahan usahatani. Traktor dalam pengolahan lahan usahatani mencapai kapasitas tertinggi yaitu $0,0425 \mathrm{Ha} / \mathrm{Jam}$ dibandingkan dengan kapasitas ternak 0,0292 $\mathrm{Ha} / \mathrm{Jam}$ dan tenaga manusia 0,0021 Ha/Jam. Biaya pengolahan lahan tertinggi dengan tenaga manusia $\mathrm{Rp}$ 1.610.227/hektar, dan biaya terendah dengan menggunakan ternak Rp 364.127/hektar, sedangkan besarnya biaya penggunaan traktor berada diantara keduanya, yaitu $\mathrm{Rp}$ 715.390/hektar. Berdasarkan kapasitas dan biaya tersebut dapat disimpulkan bahwa secara teknis penggunaan traktor paling efisien, namun secara ekonomis penggunaan ternak menunjukkan yang paling efisien.
\end{abstract}

Kata kunci: efisiensi, pengolahan lahan, traktor, ternak, manusia

\begin{abstract}
This study aims to develop a capacity analysis, the cost analysis and comparative efficiency of use of the tractor, buffalo and power man in the processing of paddy farmland. The study was conducted using survey method in the city of Tasikmalaya. Based on the analysis, of this study concluded there are significant differences amount of capacity, the cost of the use of tractor, livestock and human labor in the processing of farm land. Tractor in land processing, achieve the highest capacity 0.0425 ha/hour compared with 0.0292 ha/hour the buffalo capacity and manpower 0.0021 ha/hour For using the land with the highest human power Rp 1.610.227/ha, and the lowest cost using $R p 364.127$ cattle /ha, while the cost of the use of tractor is between them, namely Rp $715.390 /$ ha. Based on the capacity and the cost can be stated that it is technically the most efficient use of tractor, but economically use the most efficient buffalo shows.
\end{abstract}

Keywords: efficiency, land management, tractor, livestock, human

\section{PENDAHULUAN}

Berdasarkan status penguasaan lahan yang digarapnya, pelaku usahatani dapat digolongkan ke dalam empat kategori, yaitu petani pemilik, petani pemilik penggarap, petani penggarap dan buruh tani. Petani pemilik dengan proporsi $\pm 6 \%$ adalah pemilik lahan usahatani namun tidak menggarap lahan usahataninya. Lahan usahatani yang dimiliki digarap oleh orang lain yaitu oleh penggarap atau penyakap, dengan 
mendapatkan kompensasi dari orang yang menggarap atau penyakap tersebut. Petani pemilik penggarap $\pm 70 \%$ adalah petani yang menggarap lahan usahatani miliknya sendiri. Penggarap atau penyakap proporsi jumlahnya $16 \%$ adalah orang yang mengerjakan lahan usahatani milik orang lain, termasuk penyewa atau penggadai. Buruh tani \pm $8 \%$ adalah orang yang mendapat upah atas curahan tenaga kerja pada lahan usahatani. Proporsi pelaku usahatani tersebut dapat diilustrasikan sebagaimana pada Gambar 1.

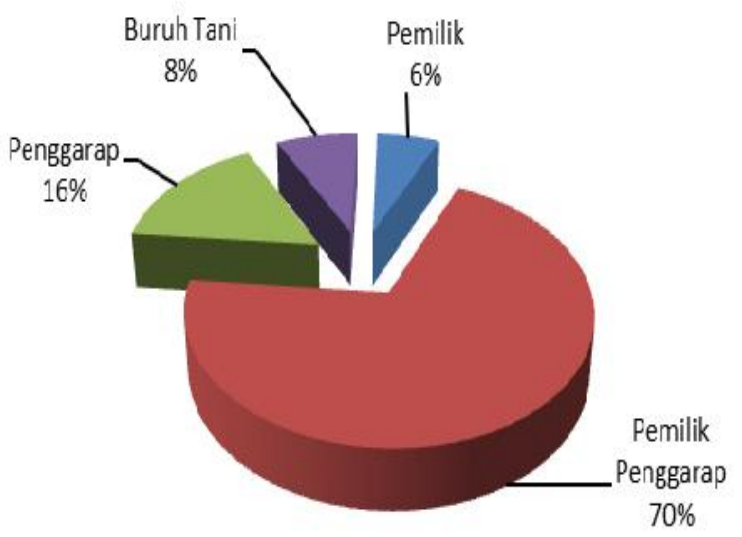

\section{Gambar 1. Proporsi Status Pelaku Usahatani di Kota Tasikmalaya Tahun 2013}

Melihat proporsi pelaku usahatani tersebut di atas, dapat diperkirakan bahwa ketersediaan tenaga kerja untuk mengelola usahatani di Kota Tasikmalaya tidak mudah. Proporsi jumlah buruh tani hanya $\pm 8 \%$, terlalu kecil dibandingkan dengan proporsi jumlah petani pemilik, petani penggarap atau penyakap. Dalam kondisi seperti ini biaya tenaga kerja untuk mengelola usahatani padi di Kota Tasikmalaya relatif tinggi. Pekerjaan yang paling banyak menyita biaya dan curahan tenaga kerja dalam mengelola usahatani adalah pada saat mengolah lahan usahatani.
Secara tradisional mengolah lahan usahatani dilakukan dengan alat cangkul. Pada awalnya pekerjaan mengolah lahan usahatani padi ini dilakukan dengan cara bergotong royong, cara bergiliran dari satu usahatani ke lahan usahatani lainnya. Namun dalam perkembangannya cara mengolah lahan dengan bergiliran tersebut tidak memungkinkan lagi dilakukan. Pengolahan lahan usahatani dikerjakan oleh buruh tani sebagai tenaga kerja upahan. Seiring dengan semakin berkembangnya sektor industri dan jasa, semakin banyak orang yang tidak lagi menekuni profesi buruh tani. 
Tenaga kerja muda yang produktif lebih banyak yang memilih bekerja sebagai buruh pabrik, berdagang atau melakukan pekerjaan apapun dan hijrah ke kota-kota besar. Mereka tidak tertarik lagi mengerjakan pekerjaan usahatani, apalagi hanya sebagai buruh tani. Kondisi seperti ini menyebabkan semakin sulitnya mencari tenaga kerja untuk mengelola usahatani di Kota Tasikmalaya. Mengelola usahatani padi sawah memerlukan tenaga kerja cukup banyak. Berdasarkan hasil wawancara di lapangan, untuk mengelola satu hektar usahatani padi sawah di Kota Tasikmalaya diperlukan tenaga kerja kurang lebih 27 Hari Kerja Pria (HKP) dan 61 Hari Kerja Wanita (HKW).

Sebagai pembanding, misalnya di sentra-sentra produksi padi di Jalur Pantura Jawa proporsi jumlah buruh tani rata-rata mencapai proporsi lebih dari 30\%. Dalam kondisi seperti ini pun di jalur pantura masih kekurangan atau kesulitan mendapatkan tenaga kerja pada saat mengerjakan usahatani. Kesulitan akan semakin nyata karena musim tanam padi dilakukan serentak sesuai dengan jadwal pengairan. Sumberdaya tenaga kerja sektor pertanian secara konvensional adalah tenaga kerja manusia dan ternak.
Seiring dengan berkembangnya kelompok sektor usaha sekunder dan tersier, yaitu sektor industri dan jasa, mendorong terjadinya pergeseran penyerapan tenaga kerja. Sektor industri dan jasa mampu membayar upah tenaga kerja yang lebih mahal dibandingkan dengan upah yang dibayarkan pada usahatani. Konsekuensi logis dari fenomena ini adalah lebih banyak orang yang tertarik bekerja di sektor non pertanian, yaitu industri dan jasa untuk mendapatkan upah yang lebih besar.

Saat ini di perdesaan dimana terdapat sentra-sentra usahatani, tidak lagi tersedia tenaga kerja yang cukup sepanjang masa untuk mengolah lahanlahan pertanian. Hal ini disebabkan semakin banyak tenaga kerja yang lebih tertarik keluar dari desa untuk bekerja di sektor industri yang mulai tumbuh di perkotaan. Sementara kebutuhan tenaga kerja sektor pertanian, khususnya untuk usahatani padi terikat dengan musim tanam, sehingga bersifat serentak dan masal. Maka timbul permasalahan kelangkaan tenaga kerja, terutama di saat musim pengolahan lahan. Pengolahan lahan usahatani merupakan jenis pekerjaan terberat dalam rangkaian pekerjaan mengelola usahatani padi, dibandingkan dengan jenis pekerjaan 


\section{KOMPARASI EFISIENSI PENGGUNAAN TRAKTOR, TERNAK KERBAU \\ DAN TENAGA MANUSIA DALAM PENGOLAHAN LAHAN USAHATANI PADI \\ Tedi Hartoyo, M. Iskandar Mamoen, Unang Atmaja, Hendar Nuryaman}

lainnya dalam mengelola usahatani padi

Di lain pihak, revolusi hijau di Indonesia telah merubah sistem pasar dan penguasaan sumberdaya di pedesaan. Pasar tenaga kerja tidak lagi didasarkan atas ekonomi kelembagaan tetapi transaksi telah berubah dan ditentukan oleh sistem ekonomi pasar secara umum. Dalam hal ini sumber tenaga kerja pengolah lahan yang tidak mampu menciptakan sistim produksi yang efisien akan tergeser dari sistem ekonomi pasar yang sedang berlaku. Tenaga kerja akan bergeser beralih profesi ke lapangan usaha yang mampu membayar lebih mahal.

Fenomena tersebut mendorong terjadinya introduksi teknologi pengolah lahan pertanian secara mekanik yaitu menggunakan bantuan alat mesin pertanian berupa traktor. Walaupun latar belakang introduksi teknologi pengolah lahan mekanik tersebut berangkat dari kebutuhan untuk mengisi kelangkaan tenaga kerja manusia dan ternak; pada lokasi dan momen tertentu dapat menimbulkan gesekan-gesekan dengan penyediaan lapangan kerja di perdesaan. Berkaitan dengan hal tersebut, penelitian ini mencoba mengidentifikasi beberapa aspek sosial ekonomi penggunaan traktor pada pengolahan lahan usahatani padi.
Titik fokus analisis dibatasi pada studi komparatif aspek teknis dan kelayakan finansial.

Introduksi teknologi usahatani yang akan diterapkan di perdesaan harus layak ditinjau dari aspek teknis, ekonomis, maupun sosial (Bachrien dan Hasanudin. 1997). Hal yang sama untuk introduksi penggunaan traktor dalam pengolahan lahan usahatani padi di wilayah Kota Tasikmalaya. Manfaat introduksi penggunaan traktor selayaknya harus memiliki manfaat yang lebih besar daripada manfaat yang diperoleh dari penggunaan tenaga kerja ternak kerbau dan tenaga kerja manusia.

Berdasarkan uraian di atas, tujuan dari penelitian ini adalah untuk mengetahui: (1) Besar rata-rata kapasitas produksi traktor, ternak kerbau dan tenaga kerja manusia dalam pengolahan lahan usahatani padi sawah. (2) Biaya pengolahan lahan usahatani padi sawah dengan traktor, ternak kerbau dan tenaga kerja manusia. (3) Perbandingan capaian tingkat efisiensi pengolahan lahan dengan traktor, ternak kerbau dan tenaga kerja manusia.

\section{METODE PENELITIAN}

Metode penelitian yang digunakan adalah metode survai, mengacu pada 
pernyataan Singarimbun dan Effendi (1995), bahwa penelitian ilmu-ilmu sosial itu dapat dibedakan atas tiga tipe, yaitu penelitian penjajagan (explorative), penelitian penjelasan (explanatory) dan penelitian penggambaran (descriptive). Berdasarkan kriteria tersebut di atas, metode yang digunakan dalam penelitian ini menggunakan metode descriptive explanatory.

Penelitian dilaksanakan di Kawasan Pertanian Tanaman Pangan Kota Tasikmalaya, meliputi area seluas 492 hektar, tersebar di 4 (empat) wilayah kecamatan, yaitu Kecamatan Purbaratu, Cibeureum, Mangkubumi dan Kawalu. Penelitian ini menggunakan dua macam data, yaitu data primer dan sekunder.

Populasi obyek penelitian ini terdiri atas petani yang berdomisili di Kawasan Pertanian Pangan Kota Tasikmalaya. Jumlah sampel penelitian sebanyak $15 \%$ (42 responden) yang ditentukan dengan menggunakan sampel acak sederhana. Komposisi sampel yang diambil adalah 25 rumah tangga petani (RTP) pengguna tenaga kerja traktor, 13 RTP pengguna tenaga kerja ternak kerbau dan 4 RTP pengguna tenaga kerja manusia.

Variabel-variabel yang dianalisis dalam penelitian ini adalah penggunaan traktor, ternak kerbau dan tenaga manusia yaitu penggunaan jasa tenaga kerja untuk mengolah lahan sawah, dalam hal ini pengolahan sawah berupa pembajakan (melonggarkan tanah) dan penggaruan (menggemburkan tanah) yang umum dilakukan di lahan basah (sawah).

Traktor dalam penelitian ini adalah traktor tangan (hand tractor) dengan alat bajak berupa singkal dan garu (sisir/rotary). Karakteristik yang membedakan berupa tingkat kekuatan/daya yang dinyatakan dalam Horse Power (HP).

Ternak kerbau yang dipakai untuk mengolah lahan yang satu unitnya terdiri atas 2 ekor, dengan alat yang digunakan berupa bajak (singkal) dan garu (sisir).

Tenaga manusia dalam penelitian ini adalah tenaga seorang pria dewasa yang digunakan jasanya sebagai pengolah lahan dengan menggunakan cangkul.

Pengukuran variabel penggunaan traktor, ternak kerbau dan tenaga kerja manusia berdasarkan skala rasio, yaitu dengan cara membandingkan:

1. Luas satu unit lahan (ha) yang diolah dengan waktu pengolahan yang dibutuhkan (jam).

2. Biaya yang dibutuhkan (Rp) untuk mengolah satu unit luas lahan (Ha).

a. Luas lahan garapan, pengukurannya, dinyatakan dalam satuan hektar. 
b. Kapasitas kerja, traktor, ternak kerbau dan kapasitas kerja manusia, dinyatakan dalan satuan hektar/jam.

c. Efisiensi teknis pengolahan lahan dinyatakan dalam perbandingan jumlah lahan yang dapat diolah per satuan waktu.

d. Efisiensi ekonomis pengolahan lahan dinyatakan dalam perbandingan biaya yang harus dikeluarkan untuk pengolahan satu satuan lahan, dan dinyatakan dalam satuan rupiah per hektar.

Sebagai konsekuensi logis dari uji banding antar kelompok dengan skala pengukuran rasio, maka tes atau uji statistik yang sesuai ialah Analisis Variansi (Anova) dilanjutkan dengan uji Least Square Different (LSD) sesuai pendapat Sudjana (1989), Steel dan Torrie (1985). Adapun uji hipotesisnya adalah:

Ho : $\mu_{1}=\mu_{2}=\mu_{3}$

$\mathrm{H}_{1}: \mu_{1} \neq \mu_{2} \neq \mu_{3}$

F hitung $>$ F tabel $\longrightarrow$ Ho ditolak

F hitung $<\mathrm{F}$ tabel $\longrightarrow$ Ho diterima

Tabel 1. Analysis of Variance (ANOVA)

\begin{tabular}{lccccc}
\hline $\begin{array}{c}\text { Sumber } \\
\text { Keragaman }\end{array}$ & $\mathrm{Db}$ & $\mathrm{JK}$ & $\mathrm{KT}$ & $\mathrm{F}_{\text {hit }}$ & $\begin{array}{c}\mathrm{F} \\
\text { tabel }\end{array}$ \\
\hline Perlakuan & $\mathrm{t}-1$ & $\mathrm{JK}_{\mathrm{p}}$ & $\mathrm{KT}_{\mathrm{p}}$ & $\mathrm{KT}_{\mathrm{p}} / \mathrm{KT}_{\mathrm{g}}$ & \\
Galat & $\mathrm{n}-\mathrm{t}$ & $\mathrm{JK}_{\mathrm{g}}$ & $\mathrm{KT}_{\mathrm{g}}$ & & \\
Total & $\mathrm{N}-1$ & $\mathrm{JK}_{\mathrm{t}}$ & & & \\
\hline
\end{tabular}

Apabila hasil ANOVA signifikan, maka dilanjutkan dengan Uji LSD

$$
\begin{aligned}
& \mathrm{LSD}_{\alpha}=\left(\mathrm{t}_{\alpha / 2}\right) \mathrm{S}_{\mathrm{x}} \\
& \mathrm{S}_{\mathrm{x}}=\sqrt{\frac{\text { KT Galat }}{\mathrm{n}_{1}}+\frac{\text { KT Galat }}{\mathrm{n}_{2}}}
\end{aligned}
$$

$t_{\alpha / 2}\left(d_{b_{\text {galat }}}\right)$ dapat dilihat pada tabel $\mathrm{t}$.

\section{HASIL DAN PEMBAHASAN}

\section{Luas Lahan Garapan}

Lahan garapan usahatani responden pengguna traktor dalam pengolahan lahan usahatani mencapai rata-rata paling luas, yaitu 0,496 hektar, dengan kisaran 0,141,26 hektar, standar deviasi 0,319; Luas lahan garapan usahatani responden pengguna ternak dalam pengolahan lahan usahataninya rata-rata 0,345 hektar, dengan kisaran 0,14-0,70 hektar, standar deviasi 0,149 , berada di urutan kedua terluas. Sementara luas lahan garapan usahatani padi responden pengguna tenaga manusia atau buruh tani dalam mengolah lahan usahataninya, merupakan satuan lahan garapan usahatani paling sempit, berkisar antara 0,07-0,11 hektar, dengan rata-rata 0,083 hektar, standar deviasi 0,018 hektar.

Data tersebut menunjukkan adanya korelasi antara luas lahan garapan usahatani dengan kapasitas tenaga kerja yang digunakan. Semakin luas lahan garapan yang diolah maka jenis pengolah 
lahan yang dipakai menggunakan tenaga pengolah yang kapasitasnya besar. Tenaga manusia atau buruh tani yang kapasitas kerjanya kecil hanya mengolah satuan-satuan hamparan lahan usahatani yang sempit.

Tabel 2. Descriptive Statistics Luas Lahan Responden

\begin{tabular}{lccccc}
\hline \multicolumn{1}{c}{ Diolah dengan } & $\mathbf{N}$ & $\begin{array}{c}\text { Minimum } \\
(\mathbf{H a})\end{array}$ & $\begin{array}{c}\text { Maximum } \\
(\mathbf{H a})\end{array}$ & $\begin{array}{c}\text { Mean } \\
(\mathbf{H a})\end{array}$ & $\begin{array}{c}\text { Std. Deviation } \\
(\mathbf{H a})\end{array}$ \\
\hline Traktor & 23 & 0,14 & 1,26 & 0,496 & 0,319 \\
Tenaga Ternak & 15 & 0,14 & 0,70 & 0,345 & 0,149 \\
Tenaga Manusia & 6 & 0,07 & 0,11 & 0,083 & 0,018 \\
\hline
\end{tabular}

Penggunaan traktor dan tenaga ternak sebagai pengolah lahan, terbatas hanya pada lahan-lahan pertanian yang memiliki aksesibilitas cukup baik. Lahan pertanian pangan yang terlalu jauh dari jalan desa atau jalan usahatani tidak bisa menggunakan traktor atau tenaga ternak. Lahan berbukit berbentuk sengkedan menyulitkan mobilisasi alsintan traktor dan ternak, maka dari itu tenaga manusia atau buruh tani lebih sesuai digunakan dalam lahan usahatani bersengked.

\section{Kapasitas Kerja}

Kapasitas tenaga kerja dalam penelitian ini didefinisikan sebagai lamanya waktu kerja yang diperlukan untuk menyelesaikan pengolahan lahan per satuan luas (hektar), sehingga kapasitas kerja identik dengan produktivitas kerja yang dinyatakan jumlah luasan lahan usahatani yang dapat diolah per satuan waktu.
Untuk mengukur produktivitas kerja dilakukan pengukuran waktu secara manual dengan menggunakan alat pengukur waktu. Hal ini dilakukan untuk responden yang pada waktu penelitian sedang melakukan pengolahan lahan usahatani, baik responden pengguna traktor, ternak kerbau ataupun tenaga manusia. Durasi pengukuran dilakukan selama obyek mulai melaksanakan kerja sampai selesai bekerja. Sementara itu untuk responden yang tidak sedang melakukan pengolahan saat dilakukan penelitian, hanya dilakukan wawancara untuk mengetahui lama pengolahan lahan pada pengolahan lahan yang dilakukan yang terakhir kali. Berdasarkan hasil pengamatan dan wawancara dengan responden, lamanya waktu yang diperlukan untuk menyelesaikan pekerjaan pengolahan lahan seluas satu hektar untuk tenaga kerja traktor, ternak kerbau dan manusia disajikan dalam Tabel 3. 
KOMPARASI EFISIENSI PENGGUNAAN TRAKTOR, TERNAK KERBAU

DAN TENAGA MANUSIA DALAM PENGOLAHAN LAHAN USAHATANI PADI

Tedi Hartoyo, M. Iskandar Mamoen, Unang Atmaja, Hendar Nuryaman

Tabel 3. Descriptive Statistics Kapasitas Kerja Traktor, Ternak dan Manusia

\begin{tabular}{lccccc}
\hline Kapasitas Kerja & $\mathbf{N}$ & $\begin{array}{c}\text { Minimum } \\
\text { (Ha/Jam) }\end{array}$ & $\begin{array}{c}\text { Maximum } \\
\text { (Ha/Jam) }\end{array}$ & $\begin{array}{c}\text { Mean } \\
\text { (Ha/Jam) }\end{array}$ & Std. Deviation \\
\hline Traktor & 23 & 0,0560 & 0,0327 & 0,0425 & 0,2799 \\
Tenaga Ternak & 15 & 0,0350 & 0,0255 & 0,0292 & 0,3268 \\
Tenaga Manusia & 6 & 0,0022 & 0,0018 & 0,0021 & 0,0220 \\
\hline
\end{tabular}

Kapasitas kerja traktor dalam mengolah lahan usahatani padi mencapai rata-rata tertinggi yaitu 0,0425 haktar/ jam, dengan standar deviasi 0,2799; Sedangkan rata-rata kapasitas kerja tenaga ternak berada di urutan kedua terbesar yaitu 0,0292 hektar/jam, dengan standar deviasi 0,3268. Berdasarkan hasil pengujian statistik pada selang kepercayaan 95 persen, diperoleh nilai $\alpha_{\text {hitung }}=$ 0,00; lebih kecil dari nilai $\alpha=0,05$, kesimpulan statistiknya adalah tolak $\mathrm{H}_{\mathrm{o}}$ sehingga dapat dinyatakan terdapat perbedaan yang signifikan kapasitas kerja traktor dengan kapasitas kerja tenaga ternak. Dalam hal ini kapasitas kerja traktor lebih besar dari pada kapasitas kerja ternak. Untuk memperkuat pernyataan tersebut di bawah ini disajikan tabel independent samples test kapasitas tenaga traktor dengan kapasitas tenaga ternak.

Tabel 4. Independent Samples Test Kapasitas Traktor dengan Tenaga Ternak

\begin{tabular}{|c|c|c|c|c|c|c|c|c|c|c|}
\hline \multirow{3}{*}{\multicolumn{2}{|c|}{$\begin{array}{c}\text { Kapasitas Traktor } \\
\text { dan } \\
\text { Tenaga Ternak }\end{array}$}} & \multicolumn{3}{|c|}{$\begin{array}{c}\text { Test for } \\
\text { Equality of } \\
\text { Variances }\end{array}$} & \multicolumn{4}{|c|}{ t-test for Equality of Means } & & \\
\hline & & \multirow[t]{2}{*}{$\mathbf{F}$} & \multirow[t]{2}{*}{ Sig. } & \multirow[t]{2}{*}{$\mathbf{t}$} & \multirow[t]{2}{*}{ Df } & \multirow[t]{2}{*}{$\begin{array}{c}\text { Sig. } \\
\text { (2-tailed) }\end{array}$} & \multirow[t]{2}{*}{$\begin{array}{c}\text { Mean } \\
\text { Difference }\end{array}$} & \multirow[t]{2}{*}{$\begin{array}{l}\text { Std. Error } \\
\text { Difference }\end{array}$} & \multicolumn{2}{|c|}{$\begin{array}{l}\text { 95\% Confidence } \\
\text { Interval of the } \\
\text { Difference }\end{array}$} \\
\hline & & & & & & & & & Lower & Upper \\
\hline \multirow{2}{*}{ Kapasitas } & $\begin{array}{l}\text { Equal } \\
\text { variances } \\
\text { assumed } \\
\end{array}$ & ,306 &, 584 & $-9,58$ & 36 & ,000 & $-10,751$ & 1,123 & $-13,028$ & $-8,474$ \\
\hline & $\begin{array}{l}\text { Equal } \\
\text { variances } \\
\text { not assumed }\end{array}$ & & & $-9,90$ & 33,24 & ,000 & $-10,751$ & 1,086 & $-12,959$ & $-8,542$ \\
\hline
\end{tabular}

Sementara itu kapasitas kerja tenaga manusia atau buruh tani dalam mengolah lahan usahatani padi mencapai urutan rata-rata terkecil, yaitu hanya 0,0021 hektar, dengan standar deviasi 0,0220; Apabila diuji secara statistik kapasitas tenaga traktor dibandingkan dengan kapasitas tenaga manusia ini menunjukkan perbedaan yang signifikan, pada selang kepercayaan 95\%. Hasil uji statistik, diperoleh diperoleh nilai $\alpha_{\text {hitung }}=0,00$; lebih kecil dari nilai $\alpha=0,05$, kesimpulan statistiknya tolak $\mathrm{H}_{\mathrm{o}}$ sehingga dapat dinyatakan terdapat perbedaan yang signifikan kapasitas kerja traktor dibandingkan dengan kapasitas tenaga 
manusia dalam mengolah lahan usahatani padi. Untuk memperkuat pernyataan tersebut, di bawah ini disajikan tabel independent samples test kapasitas tenaga traktor dengan kapasitas tenaga menusia.

Tabel 5. Independent Samples Test Kapasitas Traktor dengan Tenaga Manusia

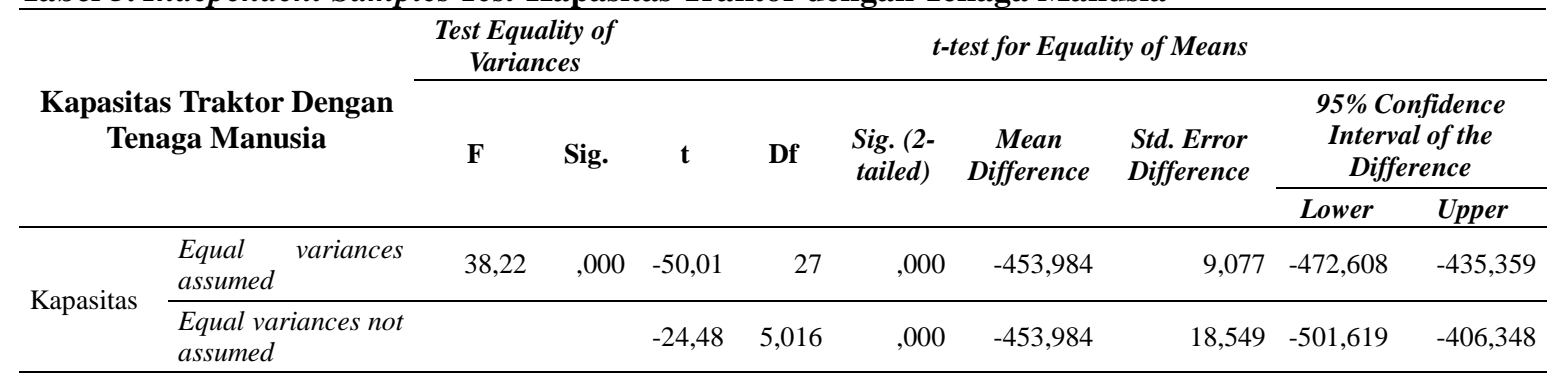

Begitu pula kapasitas tenaga kerja ternak berbeda signifikan dengan kapasitas kerja tenaga manusia atau buruh tani dalam mengolah lahan usahatani padi. Berdasarkan hasil uji statistik pada selang kepercayaan 95\%, diperoleh nilai $\alpha_{\text {hitung }}=0,00$; lebih kecil nilai $\alpha=0,05$, kesimpulan statistiknya tolak $\mathrm{H}_{\mathrm{o}}$ sehingga dapat dinyatakan terdapat perbedaan yang signifikan antara kapasitas kerja traktor dengan kapasitas tenaga manusia.

Tabel 6. Independent Samples Test Kapasitas Tenaga Ternak dengan Tenaga Manusia

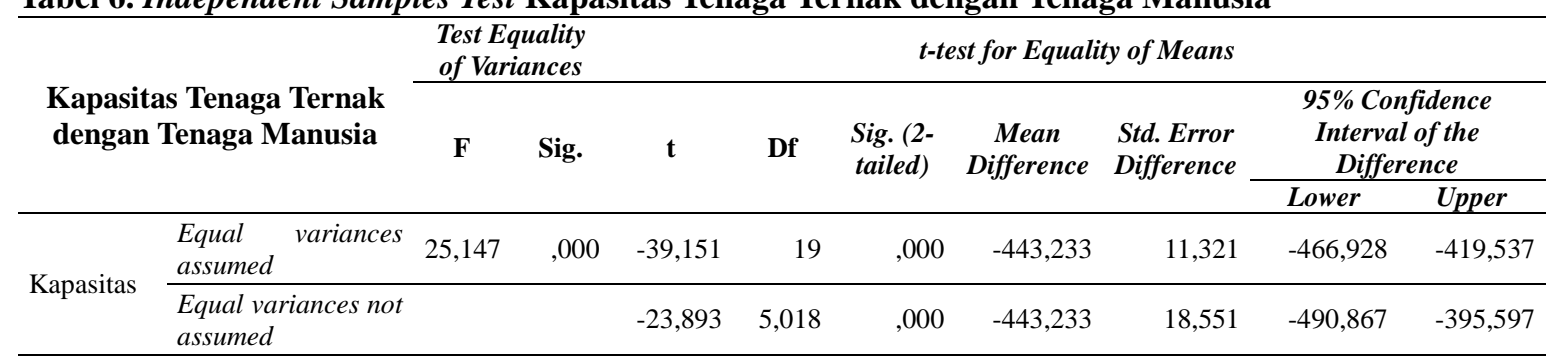

\section{Kapasitas Kerja Traktor}

Traktor di sini adalah traktor pengolah lahan usahatani padi dengan kapasitas (5,0-6,5 PK). Satuan lahan usahatani padi responden yang menggunakan traktor dalam mengolah lahan usahataninya sebanyak 23 unit. Luas lahan yang diolah dengan menggunakan traktor tidak sama, namun bervariasi dengan kisaran antara 0,14 hektar luas lahan tersempit dan usahatani terluas mencapai 1,26 hektar, sehingga rata-rata luas lahan usahatani yang diolah dengan traktor 0,4985 hektar dan standar deviasi 0,318 hektar. 
KOMPARASI EFISIENSI PENGGUNAAN TRAKTOR, TERNAK KERBAU

DAN TENAGA MANUSIA DALAM PENGOLAHAN LAHAN USAHATANI PADI

Tedi Hartoyo, M. Iskandar Mamoen, Unang Atmaja, Hendar Nuryaman

Tabel 7. Descriptive Statistics Kapasitas Kerja Traktor

\begin{tabular}{lccccc}
\hline \multicolumn{1}{c}{ Uraian } & N & Minimum & Maximum & Mean & Std. Deviation \\
\hline Luas Lahan (Ha) & 23 & 0,14 & 1,26 & 0,496 & 0,318 \\
Waktu Pengolahan (Jam) & 23 & 4,00 & 30,00 & 11,870 & 7,979 \\
Waktu Pengolah/Ha (Jam) & 23 & 17,86 & 30,61 & 23,517 & 3,573 \\
Kapasitas Kerja (Ha/Jam) & 23 & 0,056 & 0,0327 & 0,043 & 0,280 \\
\hline
\end{tabular}

Sementara itu waktu yang diperlukan untuk mengolah lahan tersebut mencapai rata-rata 11,90, dengan standar deviasi 7,98 jam, kisaran waktu paling cepat 4 jam untuk lahan yang paling sempit dan paling lama 30 jam untuk lahan yang paling luas. Berdasarkan data luasan lahan usahatani yang diolah dan waktu yang diperlukan untuk mengolah lahan tersebut dapat dihitung lamanya waktu yang diperlukan untuk mengolah lahan satu hektar berkisar antara 17,86 jam sampai 30,61 jam per hektar, sehingga diperoleh nilai rata-rata waktu 23,52 jam dengan standar deviasi 3,58 jam. Dengan kata lain, kapasitas kerja traktor dalam mengolah lahan usahatani padi sampai siap tanam mencapai rata-rata 0,0425 hektar/jam.

Sebagai pembanding hasil penelitian Ananto, dkk (1992) di Kabupaten Karawang mendapat angka rata-rata kapasitas kerja traktor 0,0515 ha/jam. Hasil penelitian lainnya Alihamsyah (1997) pada lahan pasang surut, kapasitas traktor tangan 0,053 hektar per jam.
Kapasitas kerja traktor tergantung pada spesifikasi traktor. Semakin besar spesifikasi daya (PK/HP) traktor maka akan semakin besar kapasitas daya kerjanya. Namun demikian karena luasan lahan usahatani yang diolah rata-rata sempit, sehingga tidak bisa menggunakan traktor yang berdaya besar. Penggunaan traktor di wilayah kajian berukuran antara 5-6 PK, karena penggunaan traktor yang berukuran besar menjadi kurang efisien, sehubungan dengan luasan rata-rata usahatani yang tidak luas. Seperti telah dibahas sebelumnya bahwa luasan usahatani padi di Kota Tasikmalaya lebih dari $80 \%$ berskala di bawah 0,5 hektar. Selain aspek luas satuan usahatani yang menjadi dasar pertimbangan dalam penggunaan traktor adalah aksesibilitas lahan usahatani. Tidak semua lahan usahatani dapat menggunakan traktor sehubungan dengan letaknya yang terlalu jauh dengan prasarana transportasi.

\section{Kapasitas Kerja Ternak}

Satuan usahatani padi responden yang menggunakan ternak kerbau bervariasi dengan kisaran antara 0,140- 
0,700 hektar, rata-rata luas lahan usahatani yang diolah dengan bantuan tenaga ternak 0,350 hektar standar deviasi 0,148 . Waktu yang diperlukan untuk mengolah lahan tersebut mencapai rata-rata 11,70 jam, dengan standar deviasi 4,70 jam. Waktu paling cepat 5,00 jam untuk lahan yang paling sempit dan paling lama 22,50 jam untuk lahan yang paling luas.

Tabel 8. Descriptive Statistics Kapasitas Kerja Ternak

\begin{tabular}{lccccc}
\hline \multicolumn{1}{c}{ Uraian } & N & Minimum & Maximum & Mean & Std. Deviation \\
\hline Luas Lahan (Ha) & 15 & 0,14 & 0,70 & 0,35 & 0,148 \\
Waktu Pengolahan (Jam) & 15 & 5,00 & 22,50 & 11,70 & 4,700 \\
Waktu Pengolah/Ha (Jam) & 15 & 28,57 & 39,29 & 34,27 & 3,060 \\
Kapasitas Kerja (Ha/Jam) & 15 & 0,035 & 0,026 & 0,029 & 0,327 \\
\hline
\end{tabular}

Berdasarkan data luasan lahan usahatani yang diolah dan waktu yang diperlukan untuk mengolah lahan, dapat dihitung lamanya waktu yang diperlukan untuk mengolah lahan satu hektar berkisar antara 28,57 jam sampai 39,29 jam per hektar, sehingga diperoleh nilai rata-rata waktu 34,27 jam per hektar dengan standar deviasi 3,060. Dengan kata lain, kapasitas kerja ternak dalam mengolah lahan usahatani padi sampai siap tanam mencapai rata-rata 0,029 hektar per jam.

Kapasitas tenaga kerja ternak ini lebih tinggi dibandingkan hasil penelitian Kusmayadi (1998) dan Sulaeman (1996) yang mendapat angka rata-rata kapasitas sepasang ternak kerbau sebesar 0,0240 hektar per jam. Sedangkan Ardisasmita (1986) melaporkan lebih detil lagi bahwa sepasang tenaga ternak kerbau dapat mengerjakan pengolahan lahan sawah sampai siap tanam seluas $247,5 \mathrm{~m}^{2}$ per jam dengan kecepatan 0,39 m per detik. Kapasitas kerja ternak kerbua tersebut lebih rendah dari yang dilaporkan Utoyo (1985), yang menyatakan bahwa sepasang kerbau dapat mengerjakan pengolahan lahan sawah sampai siap tanam seluas 0,07 hektar per jam.

\section{Kapasitas Kerja Tenaga Manusia/ Buruh Tani}

Luas lahan yang diolah dengan menggunakan tenaga manusia berkisar antara 0,07 hektar luas lahan tersempit dan usahatani terluas mencapai 0,11 hektar, sehingga rata-rata luas lahan usahatani yang diolah dengan buruh cangkul 0,083 hektar dan standar deviasi 0,018. Waktu yang diperlukan untuk mengolah lahan tersebut mencapai ratarata 39,83, dengan standar deviasi 9,10. Waktu paling cepat 31,50 jam untuk 


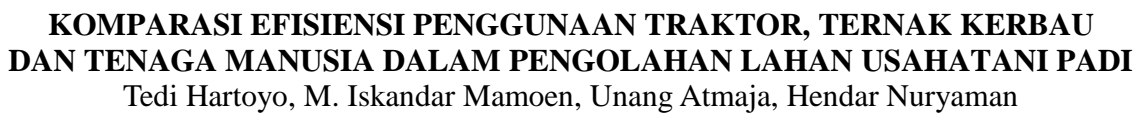

lahan yang paling sempit dan paling lama

49,50 jam untuk lahan yang paling luas.

Tabel 9. Descriptive Statistics Kapasitas Kerja Tenaga Manusia

\begin{tabular}{lcrrrr}
\hline \multicolumn{1}{c}{ Uraian } & N & Minimum & Maximum & Mean & Std. Deviation \\
\hline Luas Lahan (Ha) & 6 & 0,07 & 0,11 & 0,083 &, 018 \\
Waktu Pengolahan (Jam) & 6 & 31,50 & 49,50 & 39,83 & 9,10 \\
Waktu Pengolah/Ha (Jam) & 6 & 450,00 & 563,00 & 477,50 & 45,40 \\
Kapasitas Kerja (Ha/Jam) & 6 & 0,0022 & 0,0018 & 0,0021 & 0,0220 \\
\hline
\end{tabular}

Berdasarkan data luasan lahan usahatani yang diolah dan waktu yang diperlukan untuk mengolah lahan tersebut dapat dihitung lamanya waktu yang diperlukan untuk mengolah lahan satu hektar dengan tenaga cangkul berkisar antara 450,00 jam sampai 563,00 jam per hektar, sehingga diperoleh nilai rata-rata waktu 477,50 jam dengan standar deviasi 45,40. Dengan kata lain, kapasitas tenaga kerja buruh cangkul dalam mengolah lahan usahatani padi sampai siap tanam mencapai rata-rata 0,0021 hektar/jam.

Dasar pertimbangan yang utama pemilihan tenaga kerja manusia untuk mengolah lahan usahataninya karena lahan usahatani yang dikelolanya sempit, sehingga kalau menggunakan bantuan jasa pengolahan lahan dengan traktor atau tenaga ternak akan terjadi idle capacity. Lahan usahatani yang sempit kadangkadang cukup dengan menggunakan tenaga kerja keluarga, kalaupun menggunakan tenaga kerja upahan jumlahnya tidak terlalu besar.
Beberapa faktor yang mempengaruhi kapasitas tenaga manusia dalam mengolah lahan, diantaranya adalah usia tenaga kerja. Kapasitas tenaga kerja manusia yang berusia lanjut, tentu akan lebih kecil dibandingkan dengan kapasitas tenaga kerja yang masih berusia muda. Tenaga kerja yang sudah biasa mengolah lahan pertanian akan terlatih dan memiliki kapasitas yang lebih besar dibandingkan dengan tenaga manusia yang tidak biasa melakukan pekerjaan pengolahan lahan. Kondisi sosial ekonomi dan budaya masyarakat juga akan mempengaruhi cara kerja dan pada gilirannnya akan mempengaruhi kapasitas kerja

\section{Biaya Pengolahan Lahan}

Biaya pengolahan dengan tenaga manusia menunjukkan biaya rata-rata tertinggi; di urutan kedua tertinggi adalah pengolahan lahan dengan traktor. Sedangkan biaya termurah adalah pengolahan lahan dengan tenaga ternak. 
Biaya pengolahan lahan usahatani pengguna traktor berkisar antara $\mathrm{Rp}$ 700.000/Ha - Rp 753.968/Ha sehingga diperoleh rata-rata sebesar $\mathrm{Rp}$ 715.390/Ha, dengan standar deviasi 8,93. Sementara biaya pengolahan lahan usahatani yang menggunakan tenaga ternak kerbau berkisar antara $\mathrm{Rp}$ 285.714/Ha - Rp 476.190/Ha, sehingga diperoleh nilai rata-rata $\mathrm{Rp} 364.127 / \mathrm{Ha}$, dengan standar deviasi 41,273. Berdasarkan hasil pengujian statistik pada selang kepercayaan 95 persen, diperoleh nilai $\alpha_{\text {hitung }}=0,00$; lebih kecil dari nilai $\alpha=0,05$, kesimpulan statistiknya adalah tolak $\mathrm{H}_{\mathrm{o}}$ sehingga dapat dinyatakan terdapat perbedaan yang signifikan biaya mengolah lahan dengan menggunakan traktor dibandingkan dengan tenaga ternak. Dalam hal ini biaya pengolahan lahan usahatani dengan traktor lebih besar dibandingkan dengan biaya mengolah lahan dengan ternak.
Biaya tenaga kerja manusia atau buruh tani dalam mengolah lahan usahatani padi berkisar Rp 1.500.000/Ha - Rp 1.875.000/Ha, sehingga mencapai rata-rata yaitu $\mathrm{Rp} 1.610 .227 / \mathrm{Ha}$, dengan standar deviasi 147.53. Apabila diuji secara statistik biaya pengolahan lahan dengan traktor dibandingkan dengan biaya pengolahan lahan dengan tenaga manusia ini menunjukkan perbedaan yang signifikan pada selang kepercayaan 95\%. Hasil uji statistik, diperoleh nilai $\alpha_{\text {hitung }}=0,00$; lebih kecil dari nilai $\alpha=0,05$, kesimpulan statistiknya tolak $\mathrm{H}_{\mathrm{o}}$ sehingga dapat dinyatakan terdapat perbedaan yang signifikan biaya pengolahan lahan dengan traktor dibandingkan dengan biaya pengolahan dengan tenaga manusia. Dalam hal ini biaya pengolahan lahan dengan traktor lebih besar dari biaya pengolahan lahan dengan tenaga manusia.

Tabel 10. Descriptive Statistics Biaya Pengolahan Lahan Pertanian /Ha

\begin{tabular}{lcccrr}
\hline \multicolumn{1}{c}{ Uraian } & $\mathbf{N}$ & $\begin{array}{c}\text { Minimum } \\
(\text { Rp/Ha) }\end{array}$ & $\begin{array}{c}\text { Maximum } \\
(\text { Rp/Ha) }\end{array}$ & \multicolumn{1}{c}{$\begin{array}{c}\text { Mean } \\
(\text { Rp/Ha) }\end{array}$} & \multicolumn{1}{c}{$\begin{array}{c}\text { Std. } \\
\text { Deviation }\end{array}$} \\
\hline Biaya Traktor & 23 & 700.000 & 753.968 & 715.390 & 8.921 \\
Biaya Tenaga Ternak & 15 & 285.714 & 476.190 & 364.127 & 41.273 \\
Biaya Tenaga Manusia & 6 & 1.500 .000 & 1.875 .000 & 1.610 .227 & 147.526 \\
\hline
\end{tabular}

Pengolahan lahan usahatani dengan ternak dibandingkan dengan biaya pengolahan usahatani dengan tenaga manusia menunjukkan perbedaan yang paling besar. Biaya pengolahan usahatani dengan tenaga manusia menunjukkan biaya yang paling tinggi diantara ketiga macam penggunaan tenaga pengolah, 


\section{KOMPARASI EFISIENSI PENGGUNAAN TRAKTOR, TERNAK KERBAU \\ DAN TENAGA MANUSIA DALAM PENGOLAHAN LAHAN USAHATANI PADI \\ Tedi Hartoyo, M. Iskandar Mamoen, Unang Atmaja, Hendar Nuryaman}

sementara biaya pengolah lahan dengan ternak menunjukkan biaya termurah. Apabila diuji statistik biaya pengolahan lahan menggunakan tenaga ternak dibandingkan dengan tenaga manusia menunjukkan perbedaan yang signifikan. Pada selang kepercayaan 95\% hasil uji statistik, diperoleh nilai $\alpha_{\text {hitung }}=0,00$; lebih kecil dari nilai $\alpha=0,05$, kesimpulan statistiknya tolak $\mathrm{H}_{\mathrm{o}}$ sehingga dapat dinyatakan terdapat perbedaan yang signifikan antara biaya pengolahan lahan dengan ternak dibandingkan dengan biaya pengolahan menggunakan tenaga manusia. Dalam hal ini biaya pengolahan lahan dengan ternak lebih murah dibandingkan dengan biaya pengolahan lahan dengan tenaga manusia.

Berdasarkan ketiga macam penggunaan pengolah lahan usahatani, biaya pengolahan lahan usahatani dengan ternak kerbau merupakan biaya terendah dan biaya pengolahan lahan dengan tenaga manusia atau buruh tani cangkul menempati urutan termahal. Deskripsi uraian biaya pengolahan lahan dengan traktor, tenaga ternak dan tenaga manusia diuraikan sebagai berikut.

\section{Biaya Pengolahan Lahan dengan Traktor}

Biaya pengolahan lahan dengan traktor adalah kompensasi dari pemilik lahan usahatani untuk pemilik traktor atas jasa pengolahan lahan usahatani. Biaya pengolahan lahan ini cukup variatif tergantung luas lahan usahatani yang diolah. Luas lahan yang diolah berkisar 0,14-1,26 hektar, dengan kisaran biaya antara Rp 100.000 - Rp 950.000. Namun demikian dapat diprediksi untuk luas lahan rata-rata 0,499 hektar diperlukan biaya sebesar $\mathrm{Rp}$ 357.609, sehingga angka tersebut dapat dikonversi untuk besaran biaya pengolahan lahan per hektar dengan menggunakan traktor adalah $\mathrm{Rp}$ 715.000. lebih lengkapnya dapat dilihat pada Tabel 11 .

Tabel 11. Descriptive Statistics Biaya Pengolahan Lahan dengan Traktor

\begin{tabular}{lcccrr}
\hline \multicolumn{1}{c}{ Uraian } & N & Minimum & Maximum & Mean & Std. Deviation \\
\hline Luas Lahan (Ha) & 23 & 0,14 & 1,26 & 0,499 & 0,318 \\
Biaya pengolahan (Rp) & 23 & 100.000 & 950.000 & 357.609 & 232.016 \\
Biaya pengolahan / Ha (Rp) & 23 & 700.000 & 753.968 & 715.390 & 8.921 \\
\hline
\end{tabular}

\section{Biaya Pengolahan Lahan dengan Ternak}

Biaya pengolahan lahan dengan tenaga ternak adalah kompensasi dari pemilik lahan usahatani untuk pemilik ternak atas jasa pengolahan lahan usahatani. Biaya pengolahan lahan ini cukup variatif tergantung luas lahan usahatani yang diolah. Luas lahan yang 
diolah berkisar 0,14-0,70 hektar, dengan kisaran biaya antara $\mathrm{Rp} 50.000-\mathrm{Rp}$ 250.000, namun demikian dapat diprediksi untuk luas lahan rata-rata 0,345 hektar diperlukan biaya sebesar Rp
124.667, sehingga angka tersebut dapat dikonversi untuk besaran biaya pengolahan lahan per hektar dengan menggunakan traktor adalah Rp 364.127.

Tabel 12. Descriptive Statistics Biaya Pengolahan Lahan dengan Tenaga Manusia

\begin{tabular}{lrrrrr}
\hline \multicolumn{1}{c}{ Uraian } & N & Minimum & Maximum & Mean & Std. Deviation \\
\hline Luas Lahan (Ha) & 15 & 0,14 & 0,70 & 0,345 & 0,148 \\
Biaya pengolahan (Rp) & 15 & 50.000 & 250.000 & 124.667 & 52.626 \\
Biaya / Ha (Rp) & 15 & 285.714 & 476.190 & 364.127 & 41.273 \\
\hline
\end{tabular}

\section{Biaya Pengolahan Lahan dengan Tenaga Manusia}

Biaya pengolahan lahan dengan tenaga manusia atau tenaga buruh tani adalah kompensasi dari pemilik lahan usahatani untuk buruh tani atas jasa pengolahan lahan usahatani. Biaya pengolahan lahan ini cukup variatif tergantung luas lahan usahatani yang diolah. Luas lahan yang diolah berkisar
0,07-0,11 hektar, dengan kisaran biaya antara Rp 105.000 - Rp 180.000, namun demikian dapat diprediksi untuk luas lahan rata-rata 0,0833 hektar diperlukan biaya sebesar Rp 135.000 sehingga angka tersebut dapat dikonversi untuk besaran biaya pengolahan lahan per hektar dengan tenaga kerja manusia adalah $\mathrm{Rp}$ 1.610.227.

Tabel 13. Descriptive Statistics Biaya Pengolahan Lahan Dengan Tenaga Manusia

\begin{tabular}{lcrrrr}
\hline \multicolumn{1}{c}{ Uraian } & N & Minimum & Maximum & \multicolumn{1}{c}{ Mean } & Std. Deviation \\
\hline Luas Lahan (Ha) & 6 & 0,07 & 0,11 & 0,0833 & 0,018 \\
Biaya pengolahan (Rp) & 6 & 105.000 & 180.000 & 135.000 & 34.205 \\
Biaya pengolahan / Ha (Rp) & 6 & 1.500 .000 & 1.875 .000 & 1.610 .227$, & 147.526, \\
\hline
\end{tabular}

\section{Efisiensi Penggunaan Pengolah Lahan}

Kata efisien sering diartikan sebagai berhasil guna, konsep ekonomi yang menggambarkan penggunaan sumberdaya yang terbatas sehemat mungkin untuk mendapat manfaat yang paling maksimal. Berkaitan dengan itu,
Mubyarto (1989) dan Soekartawi (1994) mengemukakan konsep efisiensi ke dalam dua kategori, yaitu efisiensi teknis dan efisiensi ekonomis. Efisiensi teknis adalah suatu tingkat pemakaian faktor produksi dikatakan lebih efisien dari tingkat pemakaian yang lain apabila 
produk rata-ratanya lebih besar.

Sedangkan pengertian efisiensi ekonomis adalah suatu tingkat pemakaian faktor produksi dikatakan lebih efisien dari tingkat pemakaian, apabila tingkat pemakaian itu memberikan keuntungan yang lebih besar, efisiensi ekonomis tercapai pada saat keuntungan maksimum. Soekartawi (1996) memandang efisiensi tidak semata-mata dari pengaturan komposisi penggunaan faktor produksi. Konsep efisiensi juga berkaitan dengan skala usaha. Usaha yang dijalankan lebih kecil dari skala ekonomis menjadi tidak efisien. Oleh karena itu, petani perlu diarahkan supaya berusaha pada skala usaha yang menguntungkan.

Berdasarkan beberapa konsep efisiensi tersebut, maka pengertian efisiensi dalam penelitian ini digolongkan ke dalam dua kategori, yaitu efisiensi teknis yang dilihat dari perbandingan antara input produksi dengan output; dan efisiensi ekonomis yang dilihat dari besaran biaya untuk menghasilkan output.

Untuk mengukur tingkat efisiensi teknis dalam kajian ini dilihat dari besarnya kapasitas kerja, yaitu jumlah luasan lahan usahatani yang dapat diolah per satuan waktu. Dengan pendekatan tersebut dapat dilihat bahwa penggunaan traktor dalam pengolahan lahan usahatani padi menempati urutan efisiensi tertinggi. Urutan kedua dan ketiga adalah penggunaan tenaga ternak dan manusia.

Secara ekonomis, penggunaan tenaga ternak untuk mengolah lahan usahatani dinilai paling ekonomis, dan di urutan kedua adalah penggunaan traktor. Penggunaan tenaga manusia dalam mengolah lahan usahatani dinilai paling tidak efisien diantara tiga jenis pengolahan lahan tersebut.

\section{KESIMPULAN}

\section{Kesimpulan}

Kapasitas pengolahan lahan usahatani padi dengan traktor rata-rata mencapai 0,0435 hektar/jam; kapasitas tenaga kerja ternak kerbau 0,0294 ha/jam; dan kapasitas tenaga kerja manusia 0,0021 ha/jam. Kapasitas tenaga kerja ketiganya menunjukkan perbedaan yang signifikan.

Biaya pengolahan lahan usahatani padi dengan traktor, tanaga kerja ternak kerbau dan tenaga kerja manusia menunjukkan perbedaan yang signifikan pada selang kepercayaan 95\%. Biaya pengolahan lahan dengan tenaga kerja manusia Rp 1.610.227/hektar, merupakan biaya paling mahal dibandingkan dengan 
penggunaan tanaga kerja traktor $\mathrm{Rp}$ 715.390/ha, dan biaya tenaga kerja ternak yang mencapai rata-rata Rp 364.127/ha.

Secara teknis pengolahan lahan usahatani padi dengan menggunakan traktor lebih efisien jika dibandingkan dengan menggunakan ternak kerbau maupun tenaga manusia. Namun demikian secara ekonomis pengolahan lahan dengan menggunakan ternak kerbau lebih efisien jika dibandingkan dengan traktor mapun tenaga manusia.

\section{Saran}

Dalam kondisi mengejar musim tanam dengan jadwal pengaturan pengairan irigasi yang ketat, maka traktor merupakan alternatif yang tepat untuk menghemat waktu pengolahan. Namun, dalam kondisi tidak mengejar musim tanam, sebaiknya petani menggunakan ternak kerbau untuk mengolah lahan usahatani karena biayanya yang relatif paling murah.

Pemilihan tenaga kerja manusia dalam pengolahan lahan merupakan pilihan alternatif terakhir, terutama jika lahan dalam keadaan sempit dimana traktor maupun ternak kerbau tidak bisa dioperasionalkan.

\section{DAFTAR PUSTAKA}

Ananto E. E. dan A.M. Fagi, 1993. Pengolahan Tanah di Jalur pantura Jawa Barat. Risalah Seminar Puslitbang Tanaman Pangan. Pusat Penelitian dan Pengembangan Tanaman Pangan, Badan Penelitian dan Pengembangan Pertanian. Bogor.

Ananto, E.E. 1989. Mekanisasi Pertanian Dalam Usahatani Padi, dalam Buku Padi II. Pusat Penelitian dan Pengembangan Tanaman Pangan, Badan Penelitian dan Pengembangan Pertanian. Bogor.

Bachrein S., Bahtiar dan A Hasanudin, 1997. Percepatan Adopsi Teknologi Melalui Pendekatan Partisipasi Petani dan Teknologi Sederhana. Prosiding Simposium Penelitian Tanaman Pangan III. Pusat Penelitian dan Pengembangan Tanaman Pangan. Badan Penelitian dan Pengembangan Tanaman Pangan. Bogor.

Direktorat Jenderal Peternakan, 2006. Pedoman Pemanfaatan Tenaga kerja Ternak Besar. Direktorat Jenderal Peternakan. Jakarta.

Fadholi Hernanto, 1988. Ilmu Usahatani. Penebar Swadaya. Jakarta.

Masri Singarimbun dan Sofyan Efendi, 1995. Metodologi Penelitian Survey. Jakarta: LP3ES.

Mosher, A.T. 1984. Menggerakkan dan Membangun Pertanian. Disadur oleh S. Krisnandhi dan Bahrin Samad. Jakarta: Sinar Harapan.

Murti, T.W. dan G. Ciptadi. 1986. Kerbau Perah dan Kerbau Kerja. Jakarta: PT. Midiyatama Sarana Perkasa.

Soekartawi., A. Soeharjo., John. L. Dallon., J. Brian Hardaker. 1986. Ilmu Usahatani dan Penelitian Untuk Pengembangan Petani Kecil. Jakarta: UI Press. 
KOMPARASI EFISIENSI PENGGUNAAN TRAKTOR, TERNAK KERBAU

DAN TENAGA MANUSIA DALAM PENGOLAHAN LAHAN USAHATANI PADI

Tedi Hartoyo, M. Iskandar Mamoen, Unang Atmaja, Hendar Nuryaman

Sugianto, T.J., W. Prawirodihardjo dan

Sukandar, $1981 . \quad$ Kriteria

Kelayakan Tenaga Mekanik:

Evaluasi Sosial dan dan Ekonomi

Penggunaan Traktor untuk

Mengolah Sawah di Kabupaten

Bekasi Jawa Barat. Pusat

Penelitian Agro Ekonomi Bekerja

Sama dengan Fakultas Pertanian IPB, Bogor.

Sulaeman, 1996. Lama Kerja Kerbau Per Musim Kerbau Kerja Milik Anggota Kelompok Tani Ternak Dawajaya Serta Faktor-faktor Yang Mempengaruhinya. Lembaga Penelitian Universitas Padjadjaran, Bandung.

Suryadi, D. $1983 . \quad$ Prospek Perkembangan Peternakan Sapi dan Kerbau di Daerah Mekanisasi Pertanian (suatu studi di Kabupaten Subang). Thesis Magister Sains. Fakultas Pasca sarjana IPB, Bogor.
Syamsuddin Abbas, 1999. Revolusi Hijau Dengan Swasembada Beras dan Jagung. Sekretariat Pengendalian Bimas. Jakarta.

Toelihere RM., Abdul Zahid Ilyas, Cokro S Leksono, Fitri E. Desra, Widiyanti Dwi Surya, Etih Sudarnika, Basuki Setiabudi dan Agus Setiyono 1995, Pedoman Pengembangan dan Perbaikan Ternak Kerbau di Indonesia. Departemen Pertanian Direktorat Jenderal Peternakan. Jakarta.

Trip Alihamsyah, E. Eko Ananto dan Inu G. Ismail, 1997. Penelitian dan Pengembangan Alat dan Mesin Pertanian Menunjang Pertanian Tanaman Pangan di Lahan Pasang Surut. Prosiding Simposium Penelitian Tanaman Pangan III. Pusat Penelitian dan Pengembangan Tanaman Pangan Badan Penelitian dan Pengembangan Tanaman Pangan. Bogor. 